\title{
Investigations about the Formation of Incomplete Forms of Fowl Plague Virus
}

\author{
By R. RO'TT AND C. SCHOLTISSEK \\ Max-Planck-Institut für Virusforschung, Tübingen, Germany
}

(Received 10 May 1963)

\begin{abstract}
SUMMARY
During the formation of incomplete fowl plague virus, normal amounts of viral compounds are synthesized. The S-antigen, however, cannot be demonstrated within the cytoplasm in appreciable amounts by fluorescent antibody. The oligonucleotide pattern and the specific radioactivity of the ribonucleic acid (RNA) of incomplete forms are almost identical with those of standard virus. In contrast to chemically inactivated viruses no indication of multiplicity reactivation was found with incomplete forms. It is suggested that the incomplete forms are lacking in identical pieces of their genome, but contain that part of their RNA which codes for 'early protein', S-antigen and haemagglutinin.
\end{abstract}

\section{INTRODUCTION}

Incomplete forms of influenza viruses are spontaneously released from the host cell and occur when infectious viruses are passaged at a high multiplicity (von Magnus phenomenon) (von Magnus, 1954). They contain less ribonucleic acid (RNA) and ribonucleoprotein inner component (S-antigen) than complete virus (Ada \& Perry, 1955; Lief \& Henle, 1956; Rott \& Schäfer, 1961). A low infectivity/haemagglutination ratio is a characteristic of incomplete forms. Their sedimentation constant is lower than that of standard virus and they have a higher lipid content (Uhler \& Gard, 1954). The coat of the incomplete forms resembles those of standard viruses (Waterson, Rott \& Schäfer, 1961; Barry, Waterson \& Horne, 1962). They agglutinate erythrocytes like standard virus and also cause immunity and interference (von Magnus, 1954; Lief \& Henle, 1956; Rott \& Schäfer, 1961). The haemagglutinin isolated from them is identical with that from infectious virus particles (Waterson et al. 1961; Rott \& Schäfer, 1961). They are to be distinguished from viromicrosomes, which are particles with a low infectivity/haemagglutination ratio obtained from infected cells (Rott \& Schäfer, 1961).

Very little is known about the formation of incomplete influenza virus. The fowl plague virus, an influenza $\mathbf{A}$ virus, appears to be a suitable model to elucidate this problem, because it can be easily grown in tissue culture, where it produces incomplete forms under special conditions (Rott \& Schäfer, 1960). The components of fowl plague virus appear in the host cell at different times and at different sites. The S-antigen, the carrier of viral RNA, can be demonstrated in the nucleus 2-3 hr. after infection whereas the haemagglutinin can be shown $1 \mathrm{hr}$. later exclusively in the cytoplasm. In later phases of the multiplication cycle the $\mathbf{S}$-antigen emerges from the nucleus into the cytoplasm (Breitenfeld \& Schäfer, 1957). 
In the present paper a study is reported of the production of virus components, particularly RNA and S-antigen, under conditions promoting the formation of incomplete forms.

\section{METHODS}

Virus. The Rostock strain of fowl plague virus was used in all experiments. Standard virus was obtained by weekly passages of diluted virus ( $10^{1}$ to $\left.10^{2} \mathrm{LD} \mathrm{50}\right)$ in embryonated eggs.

\section{Biological tests}

Infectivity was determined by plaque test using chick embryo cells (Rott \& Schäfer, 1960). Test material was diluted in ten-fold steps in buffered saline ( $\mathrm{pH}$ $7 \cdot 2 ; 0.02 \mathrm{M}$-phosphate), containing $0.72 \%(\mathrm{w} / \mathrm{v}) \mathrm{NaCl}$ and each dilution was plated in duplicate. Plaques were counted 3 days after infection.

Complement-fixation tests were done by a modification of the micromethod of Fulton \& Dumbell (1949) described by Hennessen (1955). The complement-fixing activity of viral antigen was compared using convalescent serum from mice infected with influenza FM 1, and normal mouse serum. The convalescent serum reacts well with fowl plague S-antigen, but with neither the haemagglutinin nor the intact virus particles (Schäfer, 1957).

Haemagglutination (HA) tests were carried out by a standard method using plastic plates and a $1 \%$ suspension of chicken erythrocytes (Davenport, Rott \& Schäfer, 1960).

\section{Tissue culture}

\section{Media and solutions}

ES: $\quad$ Earle's saline +100 i.u. penicillin per ml. $+100 \mu$ g. streptomycin.

LaYe: ES with $1 \%$ lactalbumin-hydrolysate and $0.2 \%$ yeast extract.

MM: Minimal medium: ES glucose free $+5 \mathrm{~mm}$ glucose $+2 \mathrm{~mm}$ glutamine (Eagle \& Habel, 1956).

PBS: Phosphate buffered saline (Dulbecco \& Vogt, 1954).

CS : $\quad$ Filtered calf serum.

\section{Cells}

In most experiments monolayers from 11-day-old chick embryos were employed, cultured in $\mathrm{LaYe}+10 \% \mathrm{CS}$.

For experiments with fluorescent antibodies monolayers of chicken embryo lung cells were prepared. Lungs of 16-day-old chick embryos were trypsinized, the cells distributed into Petri dishes, whose bottoms were fitted with microscopic slides, and cultivated in $\mathrm{LaYe}+15 \% \mathrm{CS}$.

\section{Fluorescent antibody}

The antiserum used was prepared by immunizing a rabbit with S-antigen isolated from fowl plague virus. The preparation of fluorescent labelled antibodies, and the tests for specificity, as well as the cytological technique, were performed according to Breitenfeld \& Schäfer (1957). 


\section{RESULTS}

Occurrence of von Magnus effect with fowl plague virus in tissue culture

For undiluted passages (UP) tissue cultures were used exclusively. Monolayers of primary cultures of chick embryo cells $\left(1 \times 10^{7}\right.$ cells/Petri dish) which had been incubated in $90 \mathrm{~mm}$. Petri dishes for $24 \mathrm{hr}$. were washed once with PBS. The cells were inoculated with $2 \mathrm{ml}$. of infectious embryonic fluid, containing $5 \times 10^{8}-1 \times 10^{9}$ pfu $/ \mathrm{ml}$. (1st UP), or with $2 \mathrm{ml}$. of undiluted tissue culture medium of the preceding passages (2nd-4th UP) harvested $14 \mathrm{hr}$. post infection (p.i.). After $30 \mathrm{~min}$. adsorption at $37^{\circ}$ the cells were washed three times with PBS and covered with $6 \mathrm{ml}$. of MM. The time of addition of MM was arbitrarily taken as the start of infection (time 0 p.i.). $14 \mathrm{hr}$. p.i. the MM was removed, centrifuged $10 \mathrm{~min}$. at $3000 \mathrm{rev} . / \mathrm{min}$., and the supernatant used for the next passage. The pfu/HA ratio of the yield decreased continuously up to the 3rd UP (Fig. 1). This means that at least in the UP tested and with the conditions given above a von Magnus phenomenon occurred. These results are in accordance with those of former experiments (Rott \& Schäfer, 1960).

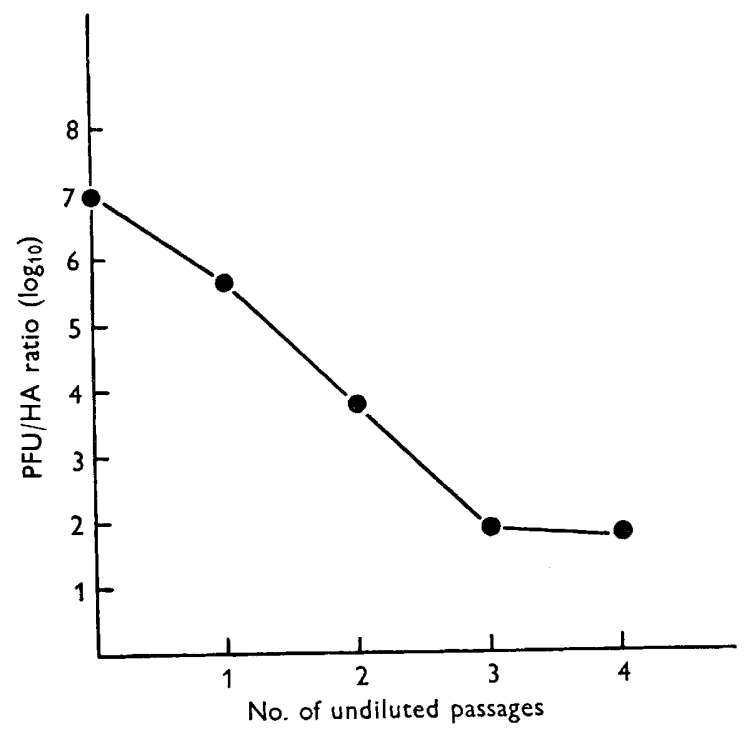
Fig. 1. Infectivity/HA ratio after undiluted passages of fowl plague virus in chick
embryo cells.

Occurrence of different biological activities of forol plague virus during undiluted passages

In order to obtain some information about the effect of the von Magnus phenomenon on the various stages of fowl plague virus multiplication, the appearance of the infectivity and of the haemagglutinating and CF activity was followed in the first 4 UP in the cells. At given intervals after infection of chick embryo cells with infectious embryonic fluid or undiluted culture medium, the MM was removed and the cell layers were washed twice with PBS. Then $2 \mathrm{ml}$. PBS containing 5\% inactivated horse serum was added to each plate, and the plates were frozen at $-40^{\circ}$. For each hourly sample, three assay plates were used. Before determining 
the various virus specific activities, the cells were scraped and frozen and thawed three times to disrupt them. Cell debris was removed by centrifugation (3000 rev.) min, $10 \mathrm{~min}$.) and the supernatant assayed. In all undiluted passages examined, the infectivity decreased in the first $2 \mathrm{hr}$. It increased markedly in the 1st UP from the 2 nd to 6 th hr. p.i. This increase was less in the 2 nd and the 4th UP. In the

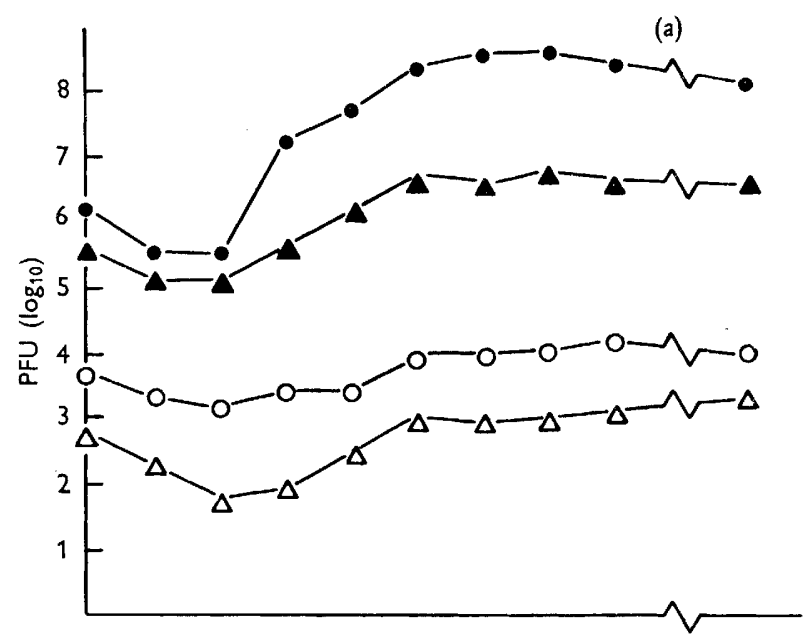

(b)
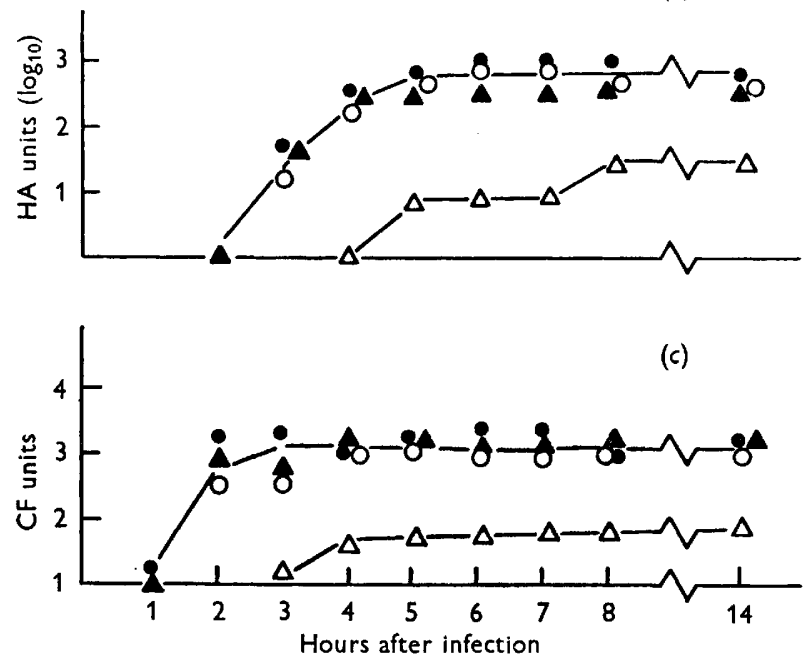

Fig. 2. Behaviour of infectivity, haemagglutinating activity and complement-fixing activity during undiluted passages in chick embryo cells. $\bullet, \Delta, O, \Delta=1$ st, 2nd, 3rd and 4th UP, respectively.

3rd UP, the infectivity remained at about the same level (Fig. 2a). Testing all UP in the plaque test the plaque yield decreased in proportion to the dilution. This means that no sign of multiplicity reactivation was observed. The plaque size, however, decreased with each successive UP, and it is possible that this occurs either by reason of interference caused by the increasing number of non-infective particles, or of a phenomenon discussed below. In comparison with the infectivity, 
the production of the two viral components (the haemagglutinin and the S-antigen) in infected cells was not quantitatively different in the first 3 UP. In these UP the $S$-antigen titre increased first between 1 and $2 \mathrm{hr}$. p.i. and reached a plateau in the 3rd hr. after infection (Fig. 2b). The haemagglutinin (Fig. $2 c$ ) began to increase between 2 and $3 \mathrm{hr}$. p.i. The maximum value for haemagglutinin was found at $5 \mathrm{hr}$. p.i. The behaviour of the haemagglutinating and CF-activities in the first 3 UP corresponds well with the data obtained by Breitenfeld \& Schäfer (1957). On the other hand, in the 4th UP S-antigen and haemagglutinin could not be demonstrated until $1 \mathrm{hr}$. later, and then in a lower concentration than in the first 3 UP. For our further studies viral materials derived from standard passages and the 2nd UP, respectively, were used.

\section{Occurrence of viral $R N A$ during undiluted passage}

In order to determine whether the RNA of the S-antigen is formed as well as the protein in UP, a chemical RNA characterization was performed. This method, using the shift in the oligonucleotide pattern of the RNA of infected cells toward that of

Table 1. Oligonucleotide pattern of $R N A$ of cells infected with standard and second $U \boldsymbol{P}$, of uninfected cells, and of purified virus $R N A$

For experimental details see Scholtissek \& Rott (1961). ${ }^{32} \mathrm{P}$ pulse from 1 to $4 \mathrm{hr}$. p.i. In Expt. $10.1 \mathrm{mC} .{ }^{32} \mathrm{P} /$ culture in Expt. $20.05 \mathrm{mC} .{ }^{32} \mathrm{P} /$ culture was used. In each case seven cultures were sampled. The counts in total RNA were calculated from the sum of the oligonucleotides determined.

\begin{tabular}{|c|c|c|c|c|c|}
\hline \multirow{2}{*}{ Expt. } & Oligonucleotide ratio & \multirow{2}{*}{$\begin{array}{c}\text { Uninfected } \\
\text { cells } \\
-\end{array}$} & \multicolumn{2}{|r|}{$\begin{array}{c}\text { Standard } \\
\text { passage }\end{array}$} & Virus* \\
\hline & $\mathbf{P f u} / \mathbf{H A}$ & & $\mathbf{2 \cdot 5}$ & $6 \cdot 2$ & - \\
\hline & $\mathbf{C} / \mathbf{U}$ & $1 \cdot 18$ & 1.05 & $1 \cdot 08$ & $0 \cdot 86$ \\
\hline & C/AC & $3 \cdot 14$ & $2 \cdot 78$ & $2 \cdot 75$ & $2 \cdot 60$ \\
\hline & C/GC & $1 \cdot 76$ & $1 \cdot 94$ & $1 \cdot 86$ & $2 \cdot 08$ \\
\hline & Total counts in RNA & 213,153 & 264,983 & 258,718 & - \\
\hline 2 & Pfu/HA & - & $\mathbf{2} \cdot \mathbf{8}$ & $5 \cdot 9$ & - \\
\hline & $\mathbf{C} / \mathbf{U}$ & $1 \cdot 25$ & $1 \cdot 09$ & $1 \cdot 04$ & $0 \cdot 86$ \\
\hline & $\mathrm{C} / \mathrm{AC}$ & $3 \cdot 27$ & $3 \cdot 04$ & $2 \cdot 98$ & $2 \cdot 60$ \\
\hline & $\mathrm{C} / \mathrm{GC}$ & $1 \cdot 79$ & $2 \cdot 02$ & $2 \cdot 03$ & $\mathbf{2 \cdot 0 8}$ \\
\hline & Total counts in RNA & 102,238 & 121,576 & 122,345 & - \\
\hline
\end{tabular}

* Taken from Scholtissek \& Rott (1961), see also Table 2.

viral RNA labelled with ${ }^{32} \mathrm{P}$, has been described in detail elsewhere (Scholtissek \& Rott, 1961). ${ }^{32} \mathrm{P}$ pulses were given in this experiment from 1 to $4 \mathrm{hr}$. p.i. The amount of RNA synthesized in the cells infected with viral material of the 2nd UP did not differ significantly from that of cells infected with a dose of standard virus sufficient to infect all the cells (Table 1). This indicates that the RNA metabolism was similar during the formation of incomplete forms and after standard infection. In addition, there was no significant difference between the samples in the shift of the oligonucleotide pattern towards that of viral RNA. This is evidence that almost as much RNA, behaving chemically like viral RNA, was synthesized in the 3rd UP as in the standard passage. 


\section{Localization of $S$-antigen in cells during the formation of incomplete forms}

Although viral RNA and S-antigen are produced in the cells under conditions of incomplete virus formation, the full amount is apparently not incorporated into the virus particles. This could result from an inhibition of the migration of the $\mathrm{S}$-antigen out of the nucleus or, on the other hand, from a disturbance of the assembly of the viral components at the cell periphery. Accordingly, we examined the localization of the S-antigen with fluorescent antibodies at different times after infection during the 3rd UP and the standard passage. Embryonic chicken lung cells were used for this purpose, since they give a clearer picture than fibroblasts. Controls showed that the pfu/HA ratio decreased in lung cells infected with the 2nd UP to the same degree as in the chicken embryo cultures used for the growth experiments. From the 4th to the 10th hr. p.i. the cells attached to the slides were fixed, stained with Santigen fluorescent antibodies and examined microscopically.

Nuclear fluorescence was already present to nearly the same degree $4 \mathrm{hr}$. p.i. in cells infected with the standard virus and the 2nd UP, indicating again that the speed of S-antigen production is nearly the same in both systems. A notable difference, however, was obtained with respect to the appearance of S-antigen in the cytoplasm in the late stages of infection. Plate 1, fig. 1 and 2, shows chicken lung cells at $10 \mathrm{hr}$. p.i. infected with standard virus and with the 2 nd UP. The fluorescence of the 3rd UP preparation is retained in the nucleus, whereas that of the standard virus preparation has spread to the cytoplasm. It seems, therefore, that during the formation of incomplete forms the bulk of the S-antigen remains in the nucleus.

\section{RNA composition of incomplete forms}

Incomplete forms may incorporate cellular RNA instead of viral RNA (Morgan, Rifkind \& Rose, 1962). In order to test this suggestion, virus of the 3rd UP was produced in the presence of ${ }^{32} \mathrm{P}$ and the oligonucleotide pattern of its labelled RNA determined. For the labelling of the virus preparations the ${ }^{32} \mathrm{P}$ was added immediately after infection. The viral material was collected $14 \mathrm{hr}$. after infection, purified by adsorption-elution with chicken erythrocytes, and by centrifugation. For details see Scholtissek \& Rott (1961). There was no significant difference between the pattern of normal viral RNA and that of the 3rd UP (Table 2). The latter shows a somewhat higher variation, but it is completely different from the pattern of total cellular RNA. The radioactivity in the RNA of the incomplete forms was about onethird of that found in standard virus. These results correspond with earlier results which were concerned with the RNA and S-antigen content (Ada \& Perry, 1955; Lief \& Henle, 1956; Rott \& Schäfer, 1961). Thus the specific activity in the RNA of standard and incomplete viruses is almost identical. The results suggest that at least the major part of the RNA contained in incomplete forms of the 3rd UP is not derived from the cellular RNA.

\section{DISCUSSION}

In the first undiluted passages of fowl plague virus in embryonic chicken cells, a von Magnus phenomenon is observed, i.e. the cells release virus with a low infectivity/ HA ratio (see also Rott \& Schäfer, 1960). In cells releasing incomplete virus the production of S-antigen and of haemagglutinin differs neither quantitatively nor 
temporally from that formed in cells producing standard virus. In addition, chemically identifiable viral RNA is produced in nearly the same quantity in the two circumstances. Studies with fluorescent antibody to the $\mathbf{S}$-antigen showed that this failed to appear in the cytoplasm when incomplete virus was being formed, as it does in cells producing standard virus. This retention of S-antigen within the nucleus may be one reason for the relatively low content of this antigen in incomplete virus, and for the fact that it never accumulates in appreciable amounts in the cytoplasm. These findings appear to conflict with those of Moffat, Holtermann \& Hillis (1960), who found less fluorescence, rather than more, in the nuclei of cells infected with large inocula of influenza virus, and who suggested that in the von Magnus phenomenon there was less S-antigen formed, and that this was the reason why less was incorporated into the virus particles. However, they used calf kidney cells, and even with low inocula the virus released has a low infectivity/HA ratio. This suggests that the multiplication cycle in calf kidney cells is not strictly comparable with that in chick embryo cells. That the low content of $\mathbf{S}$-antigen in incomplete virus released from chick cells cannot be ascribed to defective production of this antigen is supported by the fact that in chorioallantoic cells the amount of S-antigen found in the cells is nearly the same when incomplete virus is being produced as it is under standard conditions (Lief \& Henle, 1956).

Table 2. Oligonucleotide pattern of the $R N A$ of purified virus, virus from the 3rd UP, and cellular RNA, respectively

Pulse length of cellular RNA $3 \mathrm{hr}$. For the labelling of the virus preparations the ${ }^{32} \mathrm{P}$ was added immediately after infection. $3 \mathrm{hr}$. p.i. most of the viral RNA is synthesized (Scholtissek \& Rott, 1961).

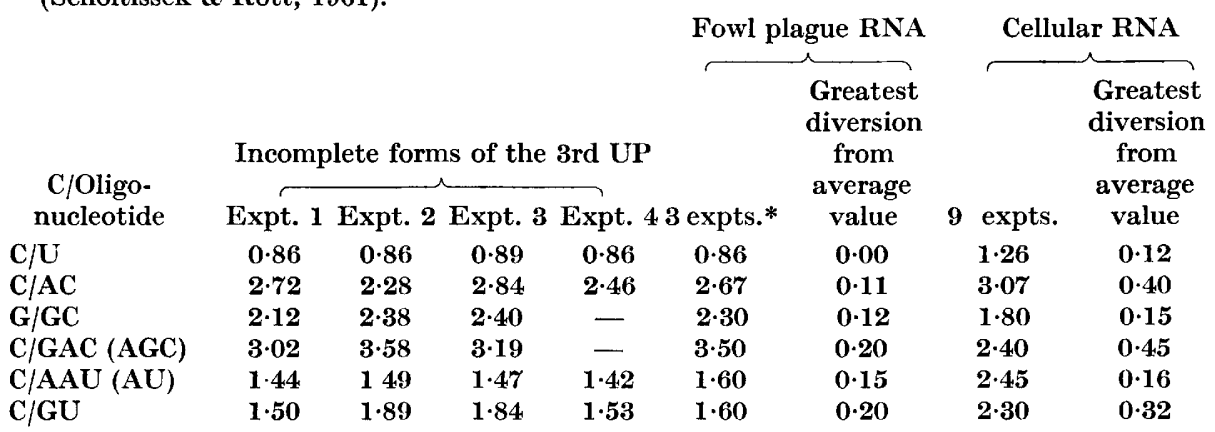

* Average of three experiments, determined together with the experiments of the 3rd UP. The values differ a little from those published earlier (Scholtissek \& Rott, 1961).

The retention of fowl plague S-antigen within the nucleus has also been observed in chick embryo cells treated with p-fluorophenylalanine (FPA) (Zimmermann \& Schäfer, 1960). The dose effect curve of FPA on the multiplication of fowl plague virus in chicken cells suggests that at low doses virus particles are produced with a low infectivity: HA ratio; this also suggests the formation of some kind of incomplete forms. Zimmermann \& Schäfer (1960) suggested that FPA causes an inhibition of the transport mechanism by a disturbance of protein synthesis. It is possible that such a transport mechanism is lacking or diminished in some other types of cell, even without treatment by FPA. For example, in Earle's L cells the S-antigen is localized strictly to the nucleus (Franklin \& Breitenfeld, 1959). Failure of the 
transport mechanism may be a common factor in all these instances, including the von Magnus phenomenon. Nevertheless, despite the extremely low infectivity, incomplete fowl plague virus may contain as much as one third of the normal amount of S-antigen. Morgan, Rifkind \& Rose (1962) suggested that cellular material might be incorporated into these forms; but it has been shown that the RNA corresponds in its oligonucleotide pattern and specific activity to that of viral RNA rather than host RNA.

The possibility that an entire content of genetic material is carried by a small number of particles, and that the remainder contain none, can be excluded by our results. On the one hand, the ability of second UP incomplete forms to induce the production of the normal amounts of S-antigen and HA within the cells, in spite of the thousand-fold lower infectivity, suggests that many particles can code for at least these two proteins. On the other hand, the number of infective particles is so low that if the genetic material were confined almost exclusively to them, there would be very much less RNA than the $30 \%$ in fact found. One possibility of unifying these observations is that the non-infective particles all lack at least one identical piece of RNA. If different particles lacked different pieces of RNA (i.e. of the viral genome) multiplicity reactivation should be demonstrable, but this is not the case. Complementation by multiple infection has not been observed. The piece of viral RNA which codes for the formation of HA must in any case be present, because the yield of HA is not significantly affected up to the 3rd UP. By way of contrast, chemically inactivated fowl plague virus, where the treatment might be expected to affect all parts of the genome, can be reactivated by multiple infection (Scholtissek, Rott \& Schäfer, 1962; Schäfer \& Rott, 1962), and the production of HA decreases rapidly and almost in parallel with the infectivity (Scholtissek \& Rott, 1963).

These groups of observations are compatible with the idea that the synthesis of the RNA or, as suggested by Hirst (1962), pieces of the RNA, starts at one end. When incomplete virus is being produced, the RNA is removed from the template before its full length is completed. That part which codes for HA, S-antigen and 'early protein(s)' (Scholtissek \& Rott, 1961) must be towards that end where synthesis begins. If one or a small number of fowl plague RNA molecules of normal length are introduced into the cell, production will proceed normally. However, the setting up of too many 'factories' in the nucleus, as in the first UP, could lead to the formation of shortened RNA because, perhaps, of a local lack of enough building blocks. Once these are produced the process could become in some sense autocatalytic. If such shortened pieces of RNA are less firmly attached to the template, and their progeny tend to release from it even earlier, shorter and shorter pieces would be produced. In the end, the RNA would be too short to code even for the HA, S-antigen and 'early protein', and the system would be exhausted. If this assumption is correct, then one should expect a diminution in the plaque size from one passage to the next, as has been observed. There are, therefore, two separate kinds of aberration to consider. First, that the virus genome itself becomes incomplete in the sense that some nucleotide sequences of the RNA, or of the pieces of RNA, are lost. Secondly, the transport out of the nucleus of the S-antigen formed within it is impaired. Our findings do not at present enable us to determine the relation of these two defects to each other. 
The authors wish to thank Professor W. Schäfer for his interest in these experiments, and Dr A. P. Waterson, and Dr E. A. Eckert for help in preparing the manuscript. The patient technical assistance of Miss D. Kunert, Mrs U. SchäferFuhr, and Mr O. Harzer, is also gratefully acknowledged. This study was supported by the Deutsche Forschungsgemeinschaft.

\section{REFERENCES}

Ada, G. L. \& Perry, D. T. (1955). Infectivity and nucleic acid content of influenza virus. Nature, Lond. 175, 209.

Barry, R. D., Waterson, A. P. \& Horne, R. W. (1962). Incomplete forms of influenza virus. Z. Naturf. $17 b, 749$.

Breitenfeld, P. M. \& SchÄFer, W. (1957). The formation of fowl plague virus antigens in infected cells, as studied with fluorescent antibodies. Virology, 4, 328.

Davenport, F. M., RotT, R. \& SchäFer, W. (1960). Physical and biological properties of influenza virus components obtained after ether treatment. J. exp. Med. 112, 765.

Dulbecco, R. \& Vogt, M. (1954). One-step growth curve of western equine encephalomyelitis virus on chicken embryo cells grown in vitro and analysis of virus yields from single cells. J. exp. Med. 99, 183.

Eagle, H. \& Habel, K. (1956). The nutritional requirements for the propagation of poliomyelitis virus by the HeLa cell. J. exp. Med. 104, 271.

Franklin, R. M. \& Breitenfeld, P. M. (1959). The abortive infection of Earle's L-cells by Fowl Plague virus. Virology, 8, 293.

Fulton, F. \& Dumbell, K. R. (1949). The serological comparison of strains of influenza virus. J. gen. Microbiol. 3, 97.

Hennessen, W. (1955). Über eine Influenza-Komplementbindungsreaktion für die Praxis. Z. Hyg. InfektKr. 141, 557.

Hirst, G. K. (1962). Genetic recombination with Newcastle disease virus, polioviruses, and influenza. Cold Spr. Harb. Symp. quant. Biol. 27, 303.

Liff, F. S. \& Henle, W. (1956). Studies on the soluble antigen of influenza virus. III. The decreased incorporation of S-antigen into elementary bodies of increasing incompleteness. Virology, 2, 782 .

Magnus, P. von (1954). Incomplete forms of influenza virus. Advanc. Virus Res. 2, 59.

Moffat, M. A. I., Holtermann, O. A. \& Hillis, W. D. (1960). The development of soluble (S) and viral (v) antigens of influenza $A$ virus in tissue culture as studied by the fluorescent antibody technique. 2. Studies employing a high multiplicity of infection in beef embryo kidney cells. Acta path. microbiol. scand. 50, 409.

Morgan, C., Rifkind, R. A. \& Rose, H. M. (1962). The use of ferritin-conjugated antibodies in electron microscopic studies of influenza and vaccinia viruses. Cold Spr. Harb. Symp. quant. Biol. 27, 57.

Rотт, R. \& SсHёFER, W. (1960). Untersuchungen über die hämagglutinierenden nichtinfektiösen Teilchen der Influenza-Viren. I. Die Erzeugung von 'Inkompletten Formen' beim Virus der Klassischen Geflügelpest. Z. Naturf. $15 b, 691$.

Rотт, R. \& SснӓFER, W. (1961). Untersuchungen über die hämagglutinierenden nichtinfektiösen Teilchen der Influenza-Viren. II. Vergleichende Untersuchungen über die physikalisch-chemischen und biologischen Eigenschaften der Teilchen. Z. Naturf. $16 b, 310$.

SCHÄFER, W. (1957). Units isolated after splitting fowl plague virus. In The Nature of Viruses. Ed. by G. E. W. Wolstenholm and E. C. P. Millar. London: Churchill.

Schäfer, W. \& Rotr, R. (1962). Herstellung von Virusvakzinen mit Hydroxylamin. Verlauf der Inaktivierung und Wirkung des Hydroxylamins auf verschiedene biologische Eigenschaften einiger Viren. Z. Hyg. InfektKr. 148, 256.

Scholtissek, C. \& RotT, R. (1961). Zusammenhänge zwischen der Synthese von Ribonukleinsäure und Protein bei der Vermehrung eines Virus der Influenza-Gruppe (Virus der klassischen Geflügelpest). Z. Naturf. 16b, 663 . 
Scholtissek, C. \& Rotr, R. (1963). Synthesis of viral ribonucleic acid by a chemically inactivated influenza virus. Nature, Lond. 199, 200.

Scholtissek, C., Rott, R. \& Schäfer, W. (1962). Verhalten von Viren gegenüber dem Bayer-Präparat A 139. Z. Naturf. 17b, 222.

UhLER, M. \& GARD, S. (1954). Lipid content of 'standard' and 'incomplete' influenza virus. Nature, Lond. 173, 1041.

Waterson, A. P., Rott, R. \& SchäfER, W. (1961). The structure of fowl plague virus and virus N. Z. Naturf. 16b, 154.

ZimmermanN, T. \& Schäfer, W. (1960). Effect of $p$-fluorophenylalanine on fowl plague virus multiplication. Virology, 11, 676.

\section{EXPLANATION OF PLATE}

Localization of S-antigen by fluorescent antibody in chicken lung cells $10 \mathrm{hr}$. after infection. Fig. 1. Inoculated with standard virus. Fig. 2. Inoculated with the second UP. 
Journal of General Microbiology, Vol. 33, No. 2

Plate 1

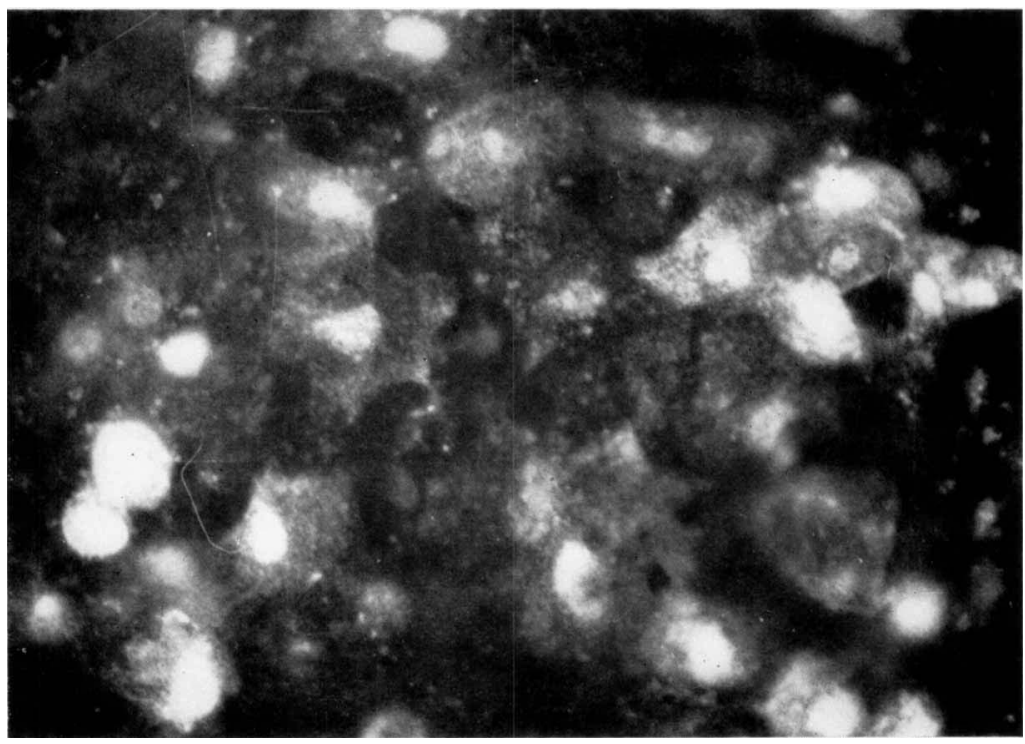

Fig. 1

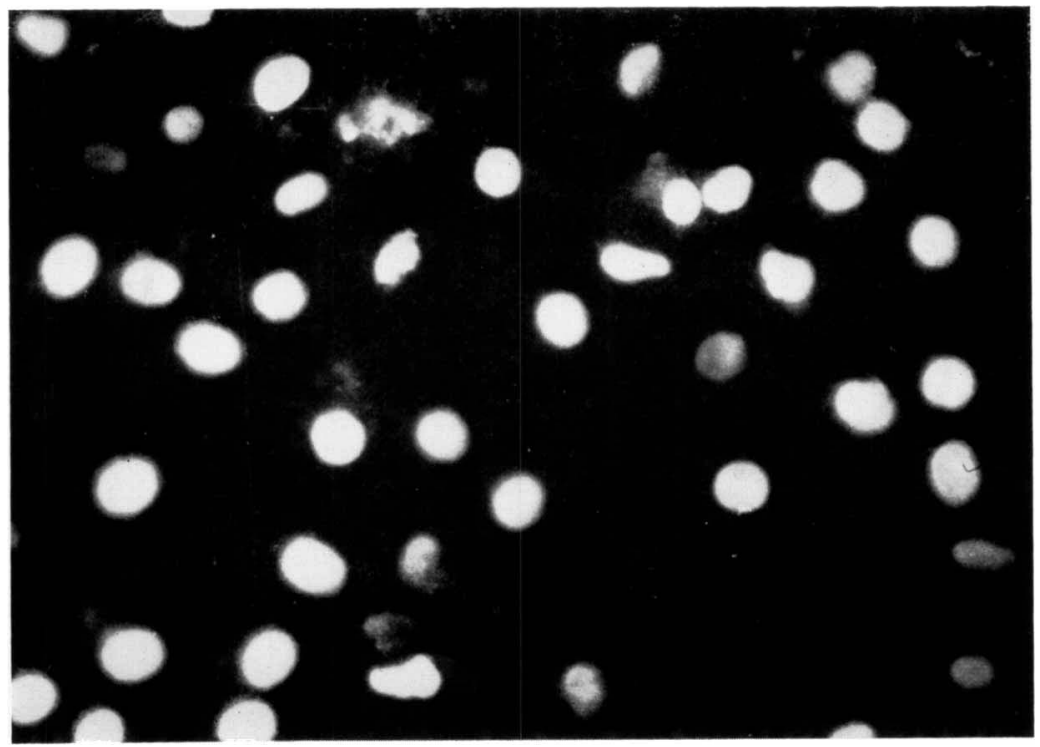

Fig. 2 